\title{
Roles of Eco-labeling in Fisheries Conservation and Sustainability
}

\author{
Olaniyi Alaba Olopade* and Henry E. Dienye \\ University of Port Harcourt, Faculty of Agriculture, Department of Fisheries, \\ PMB 5323, Port Harcourt, Rivers State, Nigeria \\ Email: olaniyi.olopade@uniport.edu.ng
}

\begin{abstract}
An important goal of fisheries management is to ensure that fish stocks are harvested at sustainable levels of fishing pressure. However, the classical maximum sustainable yield theory and its derivatives have not worked for fisheries management. A number of mitigating measures have been suggested of which eco -labeling is one. An ecolabel on a fish product is a distinctive mark or statement indicating that it has been harvested in compliance with preset sustainability standards. This paper examines eco labeling in fisheries as the new strategy to achieve fisheries conservation and sustainability. It emphasizes the importance of fish as critical food resources and new approach to fisheries management through the use of certification programs. It considers the benefits and problems that may accrue from eco-certification of fish harvesting and trade practices in fisheries. This paper, attention is focused on examining the likely option for development of eco-labeling scheme in Nigeria. The paper concludes that the increase awareness amongst stakeholders of the potential role of eco-labeling in conservation and sustainability tools should be established.
\end{abstract}

Keywords: Fisheries management, fish, conservation, eco-certification

\section{Introduction}

Many of the world's fisheries are overexploited and have wide negative effects on non-target species (e.g., marine mammals, seabirds, reptiles) and ecosystem processes and habitats (e.g., cold-water corals, sea grass meadows) (Kaiser et al., 2002). Poor management and inadequate property rights pose significant threats to the management of fisheries resources. Direct regulation has had limited success and pressures on marine resources continue to grow. The urgency of the situation caused by the successive failures in management and the need to rebuild depleted fisheries globally (Pauly et al., 2002) were recognized in the final declaration of the World Summit for Sustainable Development (WSSD) held in Johannesburg in 2002 (WSSD, 2002). A number of mitigating measures have been suggested such as community based fisheries management, ecosystem based fisheries management, establishment of marine protected area and of which eco -labeling is one. A promising direction is the independent certification programs for sustainable fisheries conducted by organizations such as the Marine Stewardship Council and Friend of the Sea. In 1997 the first certification scheme created specifically for sustainable fisheries was established in the form of the Marine Stewardship Council (MSC) (Kaiser and Edwards- Jones, 2006).
Eco-labeling has thus been seen as a means of providing incentives to the fishing community, governments, international agencies and local authorities to improve the aspects of fisheries management for which they are responsible (Nordic Technical Working Group on Eco-labeling Criteria 2000). An eco-label on a fish product is a distinctive mark or statement indicating that it has been harvested in compliance with preset sustainability standards. It is intended to encourage informed choice by consumers selecting among competing products.

Its goal is to achieve net environmental improvement along the live cycle of products. Ecolabeling fishery products have the potential to exert influence on the fishing industry to bring about changes in fishing practices. Against this background this paper set out to review the constraints and opportunities attached eco-labeling in conservation and sustainability of marine fisheries.

\section{Importance of fisheries}

Fisheries products have been an important component of the world food supply for centuries. Fish is the primary source of protein for some 950 million people world wide and represents an important part of the diet of many more (FAO, 2003). In less than 50 years, the world's average per capita 
consumption of fish has almost doubled (World Fish Center, 2002). It provides superior quality protein to that of meat, milk and eggs and well balanced essential amino acid profile, necessary minerals and fatty acids (Hossain, 1996). Fish is the primary source of omega-3 fatty acids in the human diet. Omega-3 fatty acids are critical nutrients for normal brain and eye development of infants, and have preventative roles in a number of human illnesses, such as cardiovascular disease, lupus, depression and other mental illnesses Crawford and March (1989). Today, there is increasing interest in fish consumption because of their high PUFA content. However, supply will probably be limited by environmental factors, and a likely range for demand is 150 to 160 million tons, or between 19 and $20 \mathrm{~kg}$ per person in 2030 (World Fish Center, 2002). Therefore, there is need to blend innovation, research, conservation and educational awareness into a goal of fisheries management in order to ensure sustainability of fisheries resources.

\section{Why eco-labeling?}

Fisheries are managed because the consequences of uncontrolled fishing are seen as undesirable. These consequences could include fishery collapse, economic inefficiency, and loss of employment, habitat loss or decreases in the abundance of rare species. Traditionally, the main objectives of fisheries management are categories into four: biological, economic, social and political (Hilborn, 2007). These objectives are often in conflict. That is why in the last 100 years, despite undeniable progress in ability to manage the fisheries, the status of fishery resources has deteriorated.

Cochrane et al. (2000) with studies concluding that the primary reasons for the failure of management can be summarized as: high biological and ecological uncertainty as to resource dynamics, the conflict between social and economic priorities, and the lack of definition or observance of constraints imposed by the limits to production of the resources. Moreover, another failure in traditional management systems has been the lack of attention paid to the dynamics or behaviour of the fishers as an integral part of the system (Hilborn et al., 1995). To date, the artificial separation between ecology, social sciences and economics continues to be a major impediment to understanding how a sustainable flow of ecological goods and services can be achieved (McMichael et al., 2003).

The urgency of the situation caused by the successive failures in management and the need to rebuild depleted fisheries globally (Pauly et al., 2002) were recognized in the final declaration of the
World Summit for Sustainable Development(WSSD) held in Johannesburg in 2002 (WSSD, 2002).It is now obvious that contemporary management objectives of fisheries are increasingly diverse and management and conservation are based on a much broader scientific understanding of fishers and ecosystem. A relatively new and formal definition of fisheries success involves the principles of the Marine Stewardship Council (MSC, an international body originally formed jointly by the WWF and Unilever to accredit fisheries as sustainable and well managed (Phillips et al., 2008)

\section{Eco-labeling schemes}

An eco-label is an identifier or logo that companies place on their products packaging and marketing campaigns, indicating that in all or some aspects, their products are more environmentally friendly than others on the market. Eco-labels belong to a group that has a generic name of product sustainability information systems. The label is obtained through a certification process based on a set of criteria. Eco-labeling is not a new concept, and variants on the eco-label approach are currently wide-spread in the supply of timber (Holvoet and Muys, 2004) and agriculturally based products, e.g. organically grown farm produce (Greene and Kremen 2003). Eco-labelling in fisheries gained increased impetus with the development of the nongovernment Marine Stewardship Council (MSC) in 1996 (Potts and Haward, 2007).

During the 1970s, a few small eco-labeling schemes began to emerge in some of the developed countries. In 1978, the first national eco-labeling scheme in the world, the German "Blue Angel", was introduced as a means of informing consumers of the environmental friendly aspects of products (Melser and Robertson, 2005). This effort was followed by other national schemes around the world. In 1987, the European Union (EU) introduced the idea of a supranational eco-label during the first European Year for the Environment. In 1989, the International Organization for Standardization5 (ISO) issued a basic standard: 'Environmental labels and declarations - General principles' (ISO 14020).

Eco-labeling was first internationally recognized at the 1992 UN Conference on Environment and Development (UNCED) in Rio de Janeiro. There governments agreed to "encourage expansion of environmental labeling and other environmentally related product information programmes designed to assist consumers to make informed choices."7 Through the 1990s and early 2000, the eco-labeling approach spread steadily as both developed and developing countries began to adopt it. In the last decade, several national or 
regional fisheries eco-labels have been or are being developed through arrangements that are government-linked and/or that rely on government assessments of the fishery.

In the African region there has been a wideranging review of the various forms of eco-labeling, the eco-labels already in use by African countries, and the benefits and challenges of eco-labeling in the region (UNEP, 2007a). The review was generally positive about the experience to date, the benefits of eco-labeling and the feasibility of an African regional ecolabel with fisheries as one of the target industries for application (UNEP, 2007b). Although the European Union eco-labeling programme does not currently include fishery products, the Nordic region has a long history of eco-labeling through the Nordic Swan eco-label (NE, 2008), and in 1996 the Nordic Council of Ministers established a process to develop eco-labeling criteria for sustainable fisheries (Norden, 2000). Four fisheries eco-labels are in operation or under development that are nongovernment-based: the Marine Stewardship Council, the Friend of the Sea, Naturland and the Marine Aquarium Council.

\section{Marine stewardship council}

The Marine Stewardship Council (MSC) was established in 1997 as a joint project between the then largest seafood buyer Unilever and the international conservation organization World Wildlife Fund (WWF). The MSC was initially formed by the WWF (following its experience with the operation of the similar Forestry Stewardship Council) and the company Unilever, the world's largest buyer of seafood (Sultan 1998).MSC has operated as an independent organization since 1999 (MSC, 2008). The MSC was developed with the focus of global certification of the sustainable performance of fisheries (Potts and Haward, 2005). The system encompasses any organization that processes, wholesales or retails the certified product (Potts and Haward, 2007).Despite initially poor reception for the MSC, the system is now expanding and garnering increased support from fishing-related industries, governments and NGO's as a tool to achieve increased sustainability in fisheries (Potts and Haward, 2007).

MSC sets the standard for the eco-label through its board, supported by a Technical Advisory Board. Fishery assessments are conducted by third party certification bodies, which are in turn accredited as competent to perform MSC assessments by an accreditation body that is independent of both MSC and the certification bodies. For products to carry the MSC eco-label they must meet the MSC standards both for the sustainability of the source fishery and for the integrity of the "chain of custody" through which the product passes from the fishery to the end consumer. The MSC looks critically at the condition of the stock, the impact on the environment and the management system in place. As of 2005, 14 fisheries around the world have been certified by MSC, including many of the fisheries most commonly cited as being well managed (Hilborn, 2007). The volume of MSC certified fishery production is expected to further increase significantly over the coming years. This growth reflects the increasing consumer acceptance of the MSC certification system. However, ongoing challenges faced by the MSC include maintaining consistency, effective management, stakeholder involvement, accountability and efficiency (Potts and Haward, 2007).

\section{Eco-labeling objectives}

Eco labeling has become a useful tool for governments in encouraging sound environmental practices, and for businesses in identifying and establishing markets (i.e. domestic and sometimes international) for their environmentally preferable products. Many countries now have some form of Eco-labeling in place, while others are considering program development. Commitment to clear objectives has been critical to the success of Eco labeling programs around the world. According to FAO (2003), three core objectives are generally established and pursued: 1. Protecting the environment; 2. Encouraging environmentally sound innovation and leadership; and 3. Building consumer awareness of environmental issues

Based on the experiences of successful ecolabeling programs and pertinent ISO work, a series of principles can be identified as being critical to an effective and credible program: 1. Voluntary participation; 2. Compliance to environmental and other relevant legislation; 3. Consideration of "fitness for purpose" and level of overall performance; 4. Based on sound scientific and engineering principles; 5 . Criteria must distinguish leadership; 6. Criteria must be credible, relevant, attainable, and measurable/verifiable; 7 . Independence; 8. Open and accountable process; 9. Flexibility; and 10. Consistency with ISO 14020 and ISO 14024 guiding principles (or other appropriate documents) (FAO, 2003).

\section{Benefits of eco-labeling}

Eco labeling benefits are so numerous but below are some of the important of the scheme: 1 . Eco labeling schemes may benefit conservation 
because they offer a means whereby large numbers of people can reward producers who undertake their business in an environmentally friendly manner; 2. An eco-labeling programme creates efficiency gains by increasing the information available to consumers about alternative consumption choices. The label is a cost-effective way of supplying consumers with relevant product information that may influence their purchasing and consumption decisions; 3. Given the dependence of all market economies on consumer choice, this is potentially a very powerful way for consumers to influence the behavior of many large industries; 4 . It provides a win-win situation in which there are benefits for the environment as well as for stakeholders associated with the fishery (Oloruntuyi, 2010). Labels and official signs to guaranty products quality allow consumers to make informed choice and producers to secure their market access (stability of furniture and quality, credibility), increase their income (higher price of local products) and improve their farming and fishing system (sustainable and equitable share of benefices); 5 . Benefit of certification also, include ecological improvements such as reduction in bycatch, improved data collection and improved research, better management of target stocks, and policy changes in support of sustainable fisheries (Oloruntuyi, 2010); and 6. Other benefits from the MSC certification have socioeconomic impacts these include access of fishery products, improved supplier status for fishery (Oloruntuyi, 2010).

\section{Eco-labeling tool for sustainable consumption}

Fish consumption is on the rise globally. Worldwide, per capita consumption of marine fishes has nearly doubled since the $1960 \mathrm{~s}$ ( $9 \mathrm{~kg}$ in the 1960s vs $16 \mathrm{~kg}$ in 1997 (WHO, 2006). Fish consumption per person is expected to continue to rise as result of government agencies recommending the consumption of seafood because of its nutritional value (Brunner et al., 2009).Unlike many other food products, consumers are often in dark about sources of fishery products, how it is caught and its impacts on the natural environments. In addition, the benefits of sustainable products are often poorly communicated to consumers so that they are often unable to make fully informed purchasing decisions in accordance with their preference, budget and /or conscience (Verbeke et al., 2007). However, if the rate of consumption of fisheries products is to be maintained, the fisheries resources will have to be managed on the principle of sustainability.

Sustainability may be used as synonyms for maintainability (Oxford, 1973) or the degree of difficulty which management encounters in maintaining a community or ecosystem (Pearson and Ison, 1987). Sustainable development may be defined as a development that meets the needs of the present without compromising the ability of future generations to meet their own needs (WCED, 1987). Sustainability was reinvented or resurrected as a term and an area of societal concern, from an ecological perspective in the 1970s (Conway, 1975). However government policies have included social, biophysical and economic sustainability only since 1990, as evidenced from the Bruntl and report and others.

Interest in sustainability in general and in sustainable food production and consumption more specifically has increased at all levels of the agriculture and food chain, not in the least at the consumer level (Antil, 1984). Sustainable consumption comprises a decision-making process that takes the consumer's social responsibility and the needs of future generations into account in addition to individual needs and wants (Meulenburg, 2003) this trend has resulted in the emergence of the ethical consumer, who perceives a direct link between what is consumed and the social issue itself (Shaw and Clarke, 1999).

\section{Problems of eco-labeling scheme in conservation and sustainability in marine fisheries}

A range of issues may limit the wider uptake of MSC eco-labeled product. These include: 1. A general lack of consumer concern for marine fishes and sustainable fisheries; 2. An absence of guaranteed continued financial benefits to participating fishers, and difficulties of quality assurance that are related to complexities of monitoring compliance of marine fisheries; 3. Lack of financial (Mathew, 2000) and institutional capacity (Kuperan and Gardiner, 2000) will hinder the ability of developing country fishing management units to undertake certification, or to engage the necessary scientific expertise; 4 . It is apparent that property rights over the fishery seem to be an essential prerequisite for engagement in MSC, and this is one major impediment to wider uptake. "Without addressing the issues of access nor property rights to the coastal seas, product labels alone will be non-starters for achieving sustainability" (Kurien, 2000); 5. Small scale fisheries in developing countries are often characterised by overlapping multispecies, multi gear harvesting involving both commercial and artisanal sectors. Because they are typically inshore fisheries, exclusion and monitoring are difficult, so that many have open access regimes with little ability to manage individual stocks or enforce zoning regulations; 6 . Granting certification to one group in a fishery could potentially disenfranchise the poorer 
partners; and 7. Lack of enlightenment on ecolabelling products. Fish consumers are not aware of sustainability issue in fisheries not to talk of ecolabeling fishery products. Therefore, the consumers will not value the goods being certified.

\section{Options for future developments of eco-labeled fishery products in Nigeria}

Nigeria has extensive aquatic ecosystems that are very rich in many aquatic organisms particularly diverse fish species and her fishery systems are in favour fish eco-labeling scheme because of the following: 1 . It is noticeable that all of the currently certified MSC fisheries are associations of individuals or companies that behave collectively, and have an input into the management process (comanagement). So the formation of a greater number of fishing cooperatives would provide a mechanism for better collective decision making and strategy with respect to harvesting practices and behavior (e.g. Gelcich et al., 2005). In Nigeria, such participation is not new in the cultural setting of fishers. What is new is perception of policy makers in involving the local fishers in finding solution to problem of over exploration of a fishery; 2 . Government intervention appears to be a fundamental first step towards developing the underpinning structures that would enable currently disparate fishers to modify their behavior appropriately to achieve the requirements for MSC certification. In Chile Government policy has effectively forced fishers to work collectively to submit applications for management responsibility for defined areas of the sea (Gelcich et al., 2005). Therefore, the wider aspect of certification is a government responsibility. For certification to work in Nigeria government will needs to play a strong role by financing of certification; and 3 . Efforts should be channeled to increase awareness amongst stakeholders of the use of eco-labeling as a conservative and sustainability tool in fisheries.

\section{Conclusion}

This article has shown that eco labeling scheme as appropriate instrument for conservation and sustainability of fisheries resources. In order to make eco-labeling scheme popular and acceptable to the fish consumers, increase awareness amongst stakeholders of the potential role of eco-labeling in conservation and sustainability tools should be established, fishery sectors should form themselves into cooperative society and government intervention is also very paramount. Also consumers should be aware of the need for sustainability in their purchasing choice so as to demand for ecofriendly products.

\section{References}

Antil, J.H. 1984. Socially responsible consumers: profile and implications for public policy. J. Macro Marketing. 4(2):18-39. doi: 10.1177/ 027614678400500203

Cochrane, K.L. 2000. Reconciling sustainability, economic efficiency and equity in fisheries: the one that got away? Fish and Fisheries.1:3-21. doi: 10.1046/j.1467-2979.2000.00003.x

Conway, G.R. 1975. Agro ecosystem analysis. Agricultural Administration. 20:31-55

Crawford, M.A. \& March, D. 1989. The Driving Force: Food, Evolution, and the Future. Harper \& Row, N.Y.

Gelcich, S., Edwards-Jones, G. \& Kaiser, M.J. 2005. Importance of attitudinal differences among artisanal fishers with respect to comanagement and conservation of marine resources. Conserv. Biol. 19:1-11. doi: 10.1017/S0959270909990190

Greene, C. \& Kremen, A. 2003. US Organic farming in 2000-2001: adoption of certified systems. Agriculture Information Bull. 780:1-51.

FAO. 2003. Fisheries Management. 2. The ecosystem approach to fisheries. FAO Technical Guidelines for Responsible Fisheries. No. 4, Suppl. 2. Rome, FAO. 112p.

FAO. 2003. World Agriculture Toward 2015/2030. FAO, Rome.

Hilborn, R. \& Walters, C.J. \& Ludwing, D. 1995. Sustainable exploitation of renewable resources. Ann. Rev. Ecol. Systematics. 26:4567. doi:10.1146/annurev.es.26.110195.0004

Hilborn, R. 2007. Moving to sustainability by learning from successful fisheries. Ambio. 3(4):296303. doi : $10.1579 / 0044-7447$

Holvoet, B. \& Muys, B. 2004. Sustainable Forest Management Worldwide: A Comparative Assessment of Standards. Int. Forestry Rev. 6:99-122. doi: 10.1505/ifor.6.2.99.38388

Hossain, M.A. 1996. Proximate and amino acid composition of some potential Bangladeshi fish feed ingredients. Bangladesh J. Zool. 24:163168

Kaiser, M.J. \& Edwards-Jones, G. 2006. The role of eco-labeling in fisheries management and 
conservation. Conserv. Biol. 20:393-398. doi 101111/j.1523-1739.2006.00319x

Kaiser, M.J., Collie, J.S., Hall, S.J., Jennings, S. \& Poiner, I.R. 2002. Modification of marine habitats by trawling activities: prognosis and solutions. Fish and Fisheries. 3:114-136. doi: 10.1046/j.1467-2979.2002.00079.x

Kuperan, K.V. \& Gardiner, P. 2000. Ecolabelling and Developing Country Fisheries, Threats and Opportunities and the role for research. In Abstracts Book, The Third World Fisheries Congress, 31 October- 3 November 2000, Beijing, P.R. China.

Kurien, J. 2000. Behind the label: Are eco-labels the answer to sustainable fishing? New Internationalist 325, July 2000.

Mathew, S. 2000. Sustainable development and social well-being: Which approach for fish trade? Bridges. 4(3):11-14.

McMicael, A.J., Bulter, C.D. \& Folke, C. 2003. New visions for addressing Sustainability. Science. 302: 1919-1920. doi: 10.1126/science.1090 001

Melser, D. \& Robertson, P.E. 2005. Eco-labelling and the Trade-Environment Debate. The World Economy. 28(1):49-62. doi: 10.1111/j.14679701.2005.00674.x

Meulenburg, M. 2003. Consumer and citizen, meaning for the market of agricultural products and food products. TSL. 18: 43-56. (In Dutch).

MSC (Marine Stewardship Council). 2008. Marine Stewardship Council. See www. msc.org.

NE (Nordic Swan).2008. The Nordic Swan ecolabel. Nordic Ecolabel.

Nordic Technical Working Group on Fisheries Ecolabelling Criteria. 2000. An arrangement for the voluntary certification of products of sustainable fishing. Final Report, Copenhagen, June 2000.

Oloruntuyi, O. 2010. Winning with Certification. Samudra Report No.56 July, 2010: 26-31

Oxford. 1973. Shorter Oxford English Dictionary on Historical Principles ( $3^{\text {rd }}$ ed).Oxford: Clarendon Press.

Pauly, D., Christensen, V., Guenette, S., Pitcher, T.J., Sumaila, U., Walters, C.J., Watson, R. A. \& Zeller. D. 2002. Towards sustainability in world fisheries. Nature. 418:689-695.
Pearson, C.J. \& Ison, R.L. 1987. Agronomy of grassland systems. Cambridge University Press. p.169.

Phillips, B., Ward, T. \& Chaffee, C. eds., 2008. Ecolabelling in fisheries: what is it all about?. John Wiley \& Sons.

Potts, T. \& Haward, M., 2007. International trade, eco-labelling, and sustainable fisheries-recent issues, concepts and practices. Environment, Development and Sustainability, 9(1):91-106. doi : 10.1007/s10668-005-9006-3

Shaw , D. \& Clarke, I. 1999. Belief formation in ethical consumer groups: an exploratory study. Market Intell. Plann. 17:109-119 doi : 10.110 8/02634509910260968

Sultan, M. 1998. A new paradigm for managing marine fisheries in the next millennium, p. 51 58. In M.J. Williams (ed.) A roadmap for the future for fisheries and conservation. ICLARM Conf. Proc. 56, 58 p.

UNEP (United Nations Environment Programme). 2007a. Development of an African ecolabelling mechanism. Outcome of the Regional Consultation Process, African Union Commission, United Nations Environment Programme and the United Nations Economic Commission for Africa, 11-13 June 2007, Addis Ababa, Ethiopia.

UNEP (United Nations Environment Programme). 2007b. Background assessment and survey of existing initiatives related to eco-labelling in the African region. Final draft: 10 July 2007 . UNEP.

Verbeke, W., Vanhonack, F., Sioen, I., VanCamp, J. \& De Henaun, S. 2007. Perceived importance of sustainability and ethics related to fish: A consumer behaviours perspective. Ambio. 36(7):580-585. doi :10.1579/0044-7447

WCED. 1987 Our common future New York: Oxford University Press, p.400

World Fish Center. 2002. Fish: an issue for everyone: a concept paper for Fish for All. ICLARM. The World Fish Center, World Fish Center, Fish for All. 10 pages

WSSD (World Summit on Sustainable Development. 2002. Report of the World Summit on Sustainable Development, Johannesburg, South Africa, 26 August-4 September 2002. WSSD. 